\title{
Factors Contributing to the Decline of the Anchovy Fisheries in Krueng Raya Bay, Aceh, Indonesia
}

\author{
Zulhamsyah $\operatorname{Imran}^{1,2}$ and Masahiro Yamao \\ ${ }^{1}$ Graduate School of Biosphere Science, Hiroshima University, Higashi-Hiroshima \\ 739-8528, Japan \\ ${ }^{2}$ Department of Aquatic Resources Management, Bogor Agricultural University, \\ Kota Bogor, Jawa Barat 16680, Indonesia
}

\begin{abstract}
Anchovy fisheries in Indonesia faces an imminent collapse in the next decade. This research explores some crucial factors contributing to the overfishing or depletion of anchovy resources. It was conducted in Krueng Raya Bay during September - October 2012. Survey, focus group discussion and interviews were implemented to explore the state of anchovy and coastal ecosystem degradation. It was shown that $52 \%$ of the total production was caught by lift net boats during the west monsoon season of 2012. Simple regression analysis resulted to different models of MSY either before or after the tsunami in 2004 which were shown as $y=0.8696-$ $0.00008 \mathrm{x}$ and $\mathrm{y}=0.1138-0.00002 \mathrm{x}$, respectively. Model 1 recommended reducing the number of lift net boat to 43 units for optimization of yield. On the other hand, Model 2 suggested that only 23 units could be operated for optimal effort each year. Average recent catch in MSY showed 53.9\% (less abundant) before the tsunami and 5.5\% (depletion) after that. These conditions was led by increasing effort, un-friendly, destructive fishing gears, and degradation of coral reef and mangrove. Such a tragedy was accelerated by anthropogenic factors and compounded by the tsunami factor. The tsunami impact on anchovy fishery depletion may be lesser than the combined effects of destructive fishing and anthropogenic factors.
\end{abstract}

Keywords: Anchovy fisheries, factors contributing, maximum sustainable yield, anchovy depletion

Correspondence : Z. Imran Address: Graduate School of Biosphere Science, Hiroshima University, Higashi-Hiroshima 739-8528,Japan Tel: +81-90-6416-5499E-mail: Zulhamsyah.imran@gmail.com DOI: $10.32945 /$ atr3622.2014 


\section{INTRODUCTION}

Anchovies contribute greatly to capture fisheries in Indonesia wherein they are utilized for human consumption and as bait fish. Fish consumption gradually increased from $23 \mathrm{~kg} /$ capita/year in 2003 to 38.4 $\mathrm{kg} /$ capita/year in 2010 (Ministry of Marine Affair and Fisheries-MMAF, 2011), although there are few records showing human consumption of anchovy. Various species of anchovy are used for bait fish, such as Stolephorus devisi and S. heterolobus in Western Sumatera, Southern Java, and Southern Nusa Tenggara (Indian Ocean Tuna Tagging Program, 2000); Encrasicholina heteroloba in Ambon Bay (Ongkers, 2011), and Stolephorus commersonii in Krueng Raya Bay. Indeed, salted and dried anchovy is widely produced by small-scale processing plants which are located along the coastlines of Aceh.

Increasing demand for anchovy has resulted from both increased human consumption and need for bait fish in Indonesia. As a result, anchovy production has fluctuated, decreased during the period 20012007 (average growth -1.1\%) and increased again in the period 20082011 (average growth 4.4\%), with an average annual growth reaching 1.4\% (MMAF, 2012). However, over the past 14 years production has shown a decline in several anchovy fisheries centers including Aceh Province. Anchovy production declined to 5,516 tons (2004) from 7,062 tons (2001), being a $-21.9 \%$ decrease. It gradually dropped from 2005 to 2010, with an average decline of $-3.4 \%$ (Aceh Province Marine Affair and Fisheries (APMAF), 2001-2011).

There were several factors contributing to anchovy production decrease in Aceh Province. The most decisive factor is the rapid increase of lift net boats. The number of these boats increased from 593 units in 1994 to 607 units in 2004. After the 2004 tsunami, lift net boats dramatically dropped to 194 units, but again increased gradually to 224 units in 2012 . Another factor was environmental degradation that affected anchovy resources. Nowadays, overfishing, mangrove and coral reef destruction, and waste pollution, have become worse and they would expectedly impact on anchovy fisheries in the near future. Moreover, the tsunami indirectly influenced the declining anchovy production during the period 2005-2012.

Overfishing of anchovy resources has also occurred in Krueng Raya Bay. Unfortunately, there is no scientific report on anchovy stock for this semi close ecosystem in relation to anchovy fisheries management, but 
Factors Contributing to the Decline of the Anchovy Fisheries

those focusing only on social and economics aspect do exist (Muchlisin et al., 2012; Lisna and Sofyan, 2012; Miftachuddin, 2007). Our study in 2012 found that anchovy production showed a sharp decrease from 2,072 tons in 1999 to 1,050 tons in 2004 and dramatically declined further to 171 tons an aftermath of the tsunami (Imran and Yamao, 2014). Anchovy production showed fluctuation in the period 2005-2009. It was less than its pre-tsunami production that reached 126.57 tons in 2012. On the contrary, the number of lift net boats increased from 8 units in 2005 to 31 units in 2009. In-depth interviews with the Panglima Laot Lhok (sea commander, hereinafter called PLL) in 2012 indicated that both coral reef and mangrove ecosystem degradation were decisive factors in reducing anchovy catch before and after the 2004 tsunami.

Several researches identified that major factors of the depletion of anchovy resources around the world were overfishing (Clark, 1977), and El Niño in the 1970s and during 1982-1983 (Clark, 1977; Hilborn and Walters, 2001). Daskalov and Mamedov (2007) reported that the combination of competitive pressure with jellyfish (Mnemiopsis ledyi) and environmental condition led to the depletion of anchovy kilka (Clupeonella engrauliformis) in the Caspian Sea during the period 2001-2005. However, not many researches paid attention on what natural disasters can directly and indirectly do to the anchovy fisheries.

Past data were not appropriate to fully account for the anchovies' state and condition. Scientific data are also limited to reveal whether anchovy fisheries are subjected to either overfishing or depletion in Krueng Raya Bay. Therefore, this study aims to explore some crucial factors contributing to overfishing or depletion of anchovy resources in Krueng Raya Bay. The specific objectives of this research are to identify the characteristics of anchovy resources; to examine the maximum sustainable yield (MSY) of anchovy before and after the tsunami; and, to examine the state of anchovy stock categories.

\section{MATERIALS AND METHODS}

The research was conducted in Krueng Raya Bay which is located on the edge of Malacca Strait and North Sea waters (Figure 1). It is strategically positioned for anchovy fisheries center. Intensive data collection was conducted in four villages (desas), i.e., Ruyung, Meunasah Keudee, Meunasah Kulam and Meunasah Mon. Primary data of some biological aspect of anchovy were collected through sampling survey in the 
period Sept-Oct 2012 using lift net fishing gears which are commonly operated in Krueng Raya Bay. Anchovies were randomly sampled from eight areas (Figure 1) that were marked by global position system (Garmin etrex VISTA Cx). For body length and weight, anchovy samples were taken at random until they represent $10 \%$ of the total catch and amounted to 188.

This research selected 83 respondents who answered structured and semi-structured questionnaires to obtain specific information about monsoon season, anchovy catch, size of anchovy, fishing gear, fishing ground, factor affecting the decline of anchovy catch, coral reef and mangrove conditions, and lift net fisheries. Interviews and Focus Group Discussions (FGD) were also carried out to explore deeper information on why anchovy resource has continually declined. Secondary data and information, in particular about the production of anchovy, number of lift net boats, and coral reef condition, were obtained from APMAF. Production of anchovy and the number of lift net boat series data in period 1999-2012 were analyzed to assess MSY and production trend. Other secondary data, such as fisheries and ecosystem data, were sourced from available reports.

Several data analyses were conducted to document the state of anchovy fishery (Table 1), as follow: (1) anchovy's MSY was estimated using surplus production model (SPM), which is widely used in fisheries related applications (Gaertner et al., 2001), to explore the state of anchovy production; (2) length-weight relationship (LWR) and t test were determined to assess the relationship between weight and length, and growth categories; (3) descriptive statistics, comparative and fish stock classification analysis were also used to determine the state of anchovy fisheries; (4) ecosystem condition and tsunami impacts were assessed to clarify their effect on anchovy fisheries; and (5) fish identification was conducted using FAO Species Catalogue Volume 7.

A modified version of the previous study of Mohammed et al. (2007) was also inferred in this research. The percent average catch for the last two to three years in relation to the historical maximum value was used to define the state of fish stock. This study applied the percent average catch in relation to the MSY before the tsunami to determine the state of anchovy stock (Table 2). 
Factors Contributing to the Decline of the Anchovy Fisheries

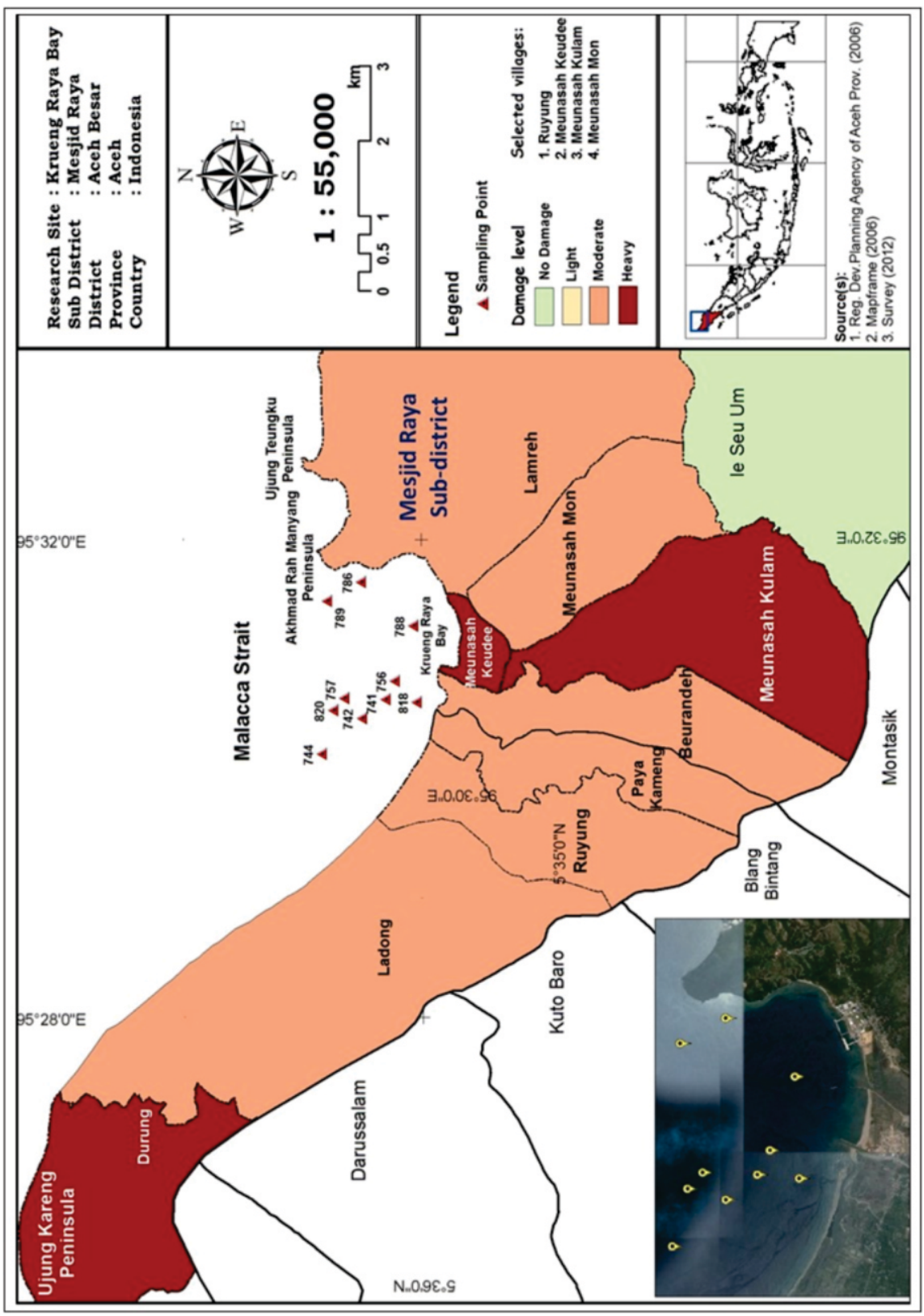

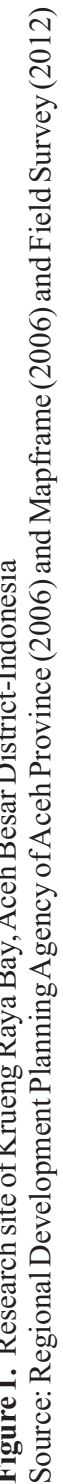


Table 1. Length-weight relationship, length size classification, and MSY analysis

\begin{tabular}{|c|c|c|c|}
\hline No. & Data Analysis & Equation & Remark \\
\hline \multirow[t]{3}{*}{1.} & Length and weight & & \\
\hline & $\begin{array}{l}\text { - Length and weight } \\
\text { relationship }{ }^{1}\end{array}$ & $\begin{array}{l}\mathrm{W}=a L^{\mathrm{b}} \\
\text { To estimate } \mathrm{a} \text { and } \mathrm{b} \text { parameter using } \\
\log \mathrm{W}=\log \mathrm{a}+\mathrm{b} \log \mathrm{L}\end{array}$ & $\begin{array}{l}\mathrm{W}=\text { total weight }(\mathrm{gram}) \\
\mathrm{L}=\text { total length }(\mathrm{mm}) \\
\mathrm{a}=\text { constant } \\
\mathrm{b}=\text { coefficient estimator }\end{array}$ \\
\hline & - $t$ test & $\begin{array}{l}\mathrm{t}_{\text {test }}=|\mathrm{b}-3| / \mathrm{Sb} \text { with the hypothesis: } \\
\mathrm{H}_{0}=3 \text {, weight growth is isometric } \\
\mathrm{H}_{1} \text { ? } 3 \text {, weight growth is allometric } \\
\text { (allwmatric growth can be positive }(\mathrm{b}>3) \\
\text { or negative }(\mathrm{b}<3)\end{array}$ & $\begin{array}{l}\mathrm{b}=\text { regression coefficient } \\
\mathrm{Sb}=\text { standard error of } \mathrm{b} \\
\mathrm{H}_{0}=\text { hypothesis null } \\
\mathrm{H}_{1}=\text { hypothesis one } \\
\text { Reject } \mathrm{H}_{0} \text { if } \mathrm{t}_{\text {test }}>\mathrm{t}_{\text {table }} \\
\text { Accept } \mathrm{H}_{0} \text { if } \mathrm{t}_{\text {test }}<\mathrm{t}_{\text {table }}\end{array}$ \\
\hline 2. & Length size classification ${ }^{2}$ & $\begin{array}{l}\mathrm{K}=1+3.3 \log \mathrm{N} \\
\mathrm{r}=\left(\mathrm{X}_{\max }-\mathrm{X}_{\min }\right) / \mathrm{K}\end{array}$ & $\begin{array}{l}\mathrm{K}=\text { a number of class } \\
\mathrm{W}=\text { interval/range } \\
\mathrm{r}=\text { wide of interval } \\
\mathrm{X}_{\max }=\text { maximum value } \\
\mathrm{X}_{\min }=\text { minimum value }\end{array}$ \\
\hline 3. & $\begin{array}{l}\text { Maximum Sustainable } \\
\text { Yield }^{1}\end{array}$ & $\begin{array}{l}\mathrm{Y}=\mathrm{a}+\mathrm{bX} \\
\text { Where } \\
\text { MSY }=\mathrm{a}^{2} / 4 \mathrm{~b} \text {, and } \\
\mathrm{f}_{\text {opt }}=\mathrm{a} / 2 \mathrm{~b}\end{array}$ & $\begin{array}{l}\mathrm{Y}=\text { catch per unit effort } \\
\mathrm{X}=\text { effort (unit/trip/years) } \\
\mathrm{a}=\text { constant } \\
\mathrm{b}=\text { coefficient estimator } \\
\mathrm{f}_{\text {opt }}=\text { effort optimal (unit/trip/years }\end{array}$ \\
\hline & Vessel optimal $^{3}$ & $V_{\text {opt }}=f o p t / \bar{e}$ & $\begin{array}{l}\mathrm{V}_{\text {opt }}=\text { vessel optimal (unit) } \\
\overline{\mathrm{e}}=\text { average trip in certain period } \\
\text { (trip/years) }\end{array}$ \\
\hline
\end{tabular}

Sources: 'Gayanilo and Pauly (1997), ${ }^{2}$ Walpole (1995) and ${ }^{3}$ modified from Gayanilo and Pauly (1997)

Table 2. Equation and criteria for fish stock classification

\begin{tabular}{|c|c|c|}
\hline Equation & $\begin{array}{c}\text { Stock } \\
\text { classification }\end{array}$ & $\begin{array}{c}\text { Recent average catch in } \\
\text { MSY }(\%)\end{array}$ \\
\hline$\%$ of recent catch in MSY $=[\bar{y} / \mathrm{MSY}] \mathrm{X} 100 \%$ & Abundant & $>80$ \\
\hline \multirow{4}{*}{$\begin{array}{l}\text { where: } \\
\text { y : average catch last three years before or after } \\
\text { tsunami; } \\
\text { MSY : MSY during the period before disaster. }\end{array}$} & Less Abundant & $50-80$ \\
\hline & Declining & $26-49$ \\
\hline & Depleted & $6-25$ \\
\hline & Collapsed & $<5$ \\
\hline
\end{tabular}

Sources: Modified from Mohammed et al. (2010)

\section{RESULTS AND DISCUSSIONS}

\section{Identification and characteristics of anchovy}

In Indonesia, anchovies are generally called "Ikan Teri", but it is known as "ikan bileh" in Aceh. Anchovies sampled in this study belonged to Stolephorus commersonii Lacepède, 1803 (Figure 2b). Fishermen in Krueng Raya Bay divide anchovies into small, medium, and big sizes. This research identified that these samples of anchovies have size ranges of 6.8 
Factors Contributing to the Decline of the Anchovy Fisheries

- $9.9 \mathrm{~cm}$ standard length (medium-big size), 5.3-8.3 g weight, a silver stripe line in the compressed body, and a little rounded belly. Commonly, $S$. commersonii is used for daily consumption and fish bait. Therefore, it can become a commercial species for the fishing communities to earn income and sustain their livelihood.

(a)

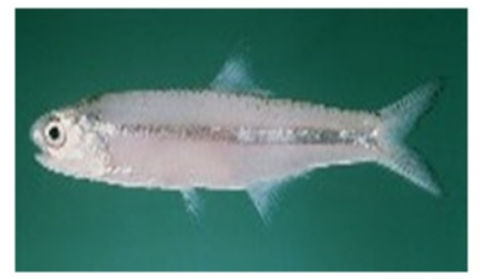

(b)

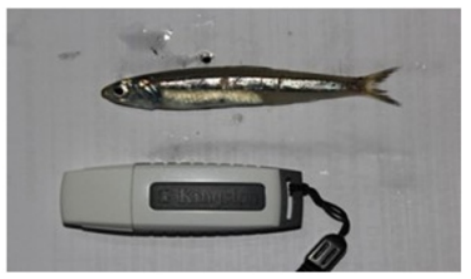

Figure 2. Stolephorus commersonnii (Randall, J.E. 1995) (a), Stolephorus commorsonii (Doc. Imran 2012)(b)

A regression was calculated for all the length and weight of anchovy sample. The regression formula found was $W=0.0556 \mathrm{~L}^{1.0809}\left(\mathrm{r}^{2}=0.9625\right)$. These computations did not consider: (1) the LWR of the juvenile; and (2) the separation of male and female samples. Regarding t test to coefficient estimator (b), it revealed that $t$ test (123) was more than $t$ table ${ }_{(0.05,187)}$ (1.972), and it means in this case to reject the null hypothesis $\left(\mathrm{H}_{0}=3\right)$. Logarithmic transformation analysis performed has revealed that $b$ (1.0809) was less than 3 . Therefore, anchovy growth could be subjected to a negative allometric growth, meaning length growth is faster than weight growth (Gayanilo and Pauly, 1997).

\section{Production trend}

As regards production change in Krueng Raya Bay, the anchovy fisheries can be categorized into three distinct periods, namely: (i) before the tsunami disaster (1999-2004), (ii) after the tsunami (2005-2006), and (iii) the recovery process period (2007-2012). Before the tsunami, anchovy production showed a decreasing trend (Figure 3). Anchovy catch dropped to 1,050 tons in 2004 and it sharply plummeted to 171 tons in 2005 after the tsunami. Eventually, it fluctuated between 126 and 279 tons in the period 2006-2012. Figure 3 also point out that actual production has been less than the result of production surplus model recommendation (Figure 3). 


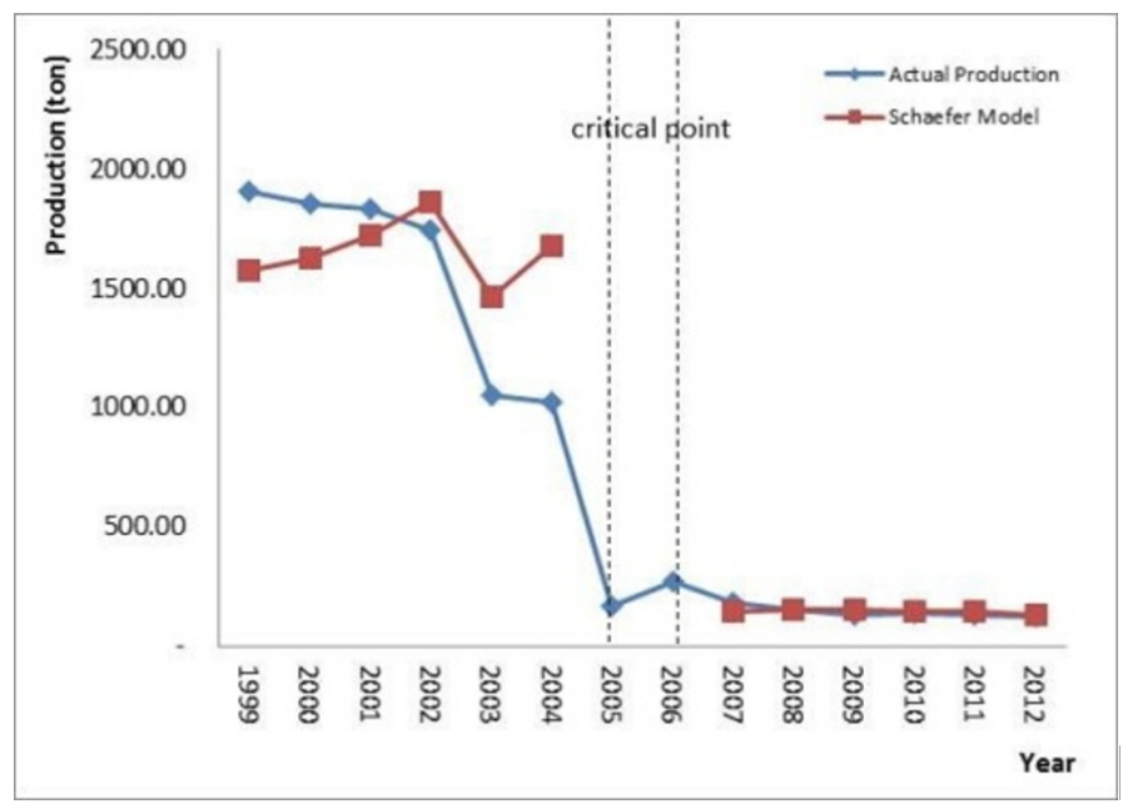

Figure 3. Comparison of actual production of anchovy and Surplus Production Model recommendation in the period 1999-2012, Sources: APMAF (2000-2012) and Data Analysis (2013)

During the field survey on September-October 2012, anchovy catch was very low in the east monsoon season. With the operation of 7-29 units of lift net boats, anchovy production was 7.8 tons. Average catch per unit effort (CPUE) reached $13.5 \mathrm{~kg} /$ day or total catch of $100-425 \mathrm{~kg} /$ day. During this operation, anchovy catch composition was $52 \%$ of the total catch. Other small pelagic fish catch composition were sardines (Sardinella sp., 25\%), pony fishes (Leiognathus sp., 14\%), yellow tail trevally (Caranx sp., 6\%) and mackerels (Decapterus sp., 3\%).

Fishing operation in the monsoon seasons

As a typical fishing gear operated only in the coastal water zone, lift net boats can catch various small pelagic fishes including anchovy throughout the year. Fishing operation starts at $0430 \mathrm{H}$ and finishes the following morning at $0700 \mathrm{H}$. Various pelagic fish species were caught and total volume of catch differs between west (October-March) and east monsoon season (April-September). 
Factors Contributing to the Decline of the Anchovy Fisheries

The size of anchovy caught is diversed during the east and west monsoon seasons. The change in anchovy size occurs as follow: first, small anchovy was caught in the beginning of the east monsoon season (JuneJuly) and the west monsoon season (October-November) when wind and waves were calm. Second, both medium and big sized anchovies were usually harvested from August to September and from February to April (at the end of west and east monsoon seasons, respectively) when wind and waves were gradually changing from moderate to strong. Third, other small pelagic species such as sardines, pony fishes, mackerels and yellow tail trevallies were harvested in the same season when medium and big anchovies are caught. This research found that 23\% and $15 \%$ of anchovy size were distributed within intervals of 84.4-88.4 $\mathrm{mm}$ and 88.5-92.5 $\mathrm{mm}$ during the period September-October 2012, respectively (Figure 4). The mean of total length value was $84 \pm 0.02 \mathrm{~mm}$; thus, it can be classified as adult stage.

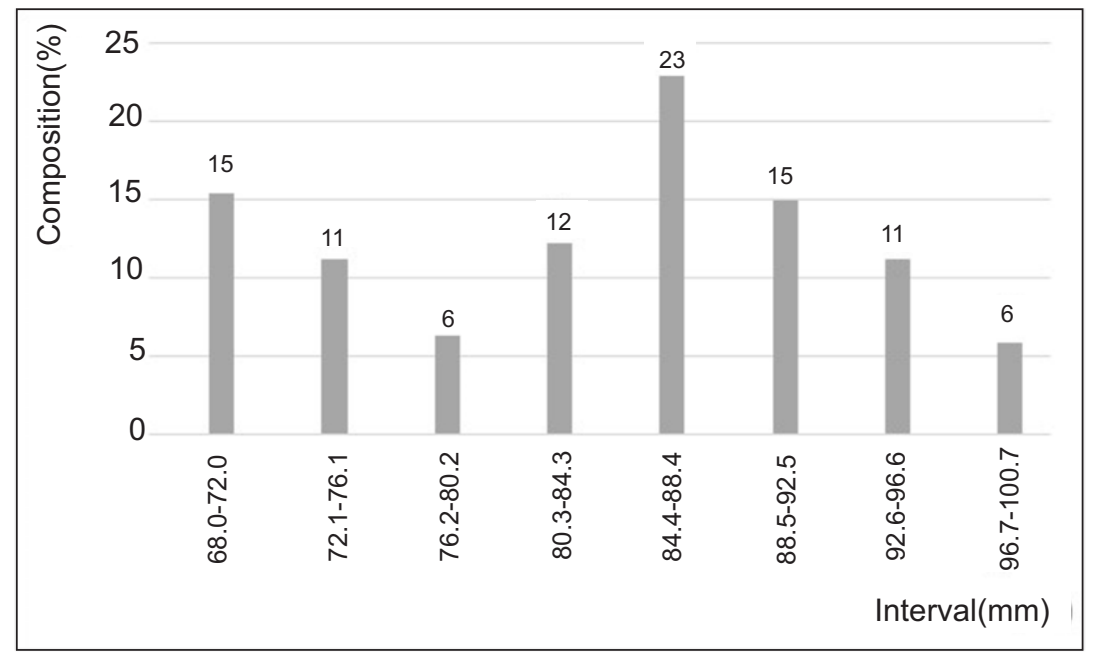

Figure 4. The size class of anchovy's distribution in the period September-October 2012

Sources: Data Analysis (2013)

\section{Maximum Sustainable Yield (MSY) and the State of Anchovy Stock}

MSY computation was divided to the period 1999-2004 and 20072012. Two point data were excluded to estimate MSY in both these periods because those data showed an extreme decline in anchovy production in 2005 and 2006 . These points can be called as an out liner 
point (in statistical terms it can be classified as biased data) or critical year for anchovy for stock recovery and equilibrium.

Anchovy production is significantly correlated with effort as indicated in the data for the period 1999-2012 (Table 3). When the effort reached 9,344 trips in 1999 , anchovy catch was $1,905.58$ tons. Afterward, catch volume fluctuated and fell sharply in 2003. This fact indicated that the critical point of anchovy fisheries occurred after the 2004 tsunami. Production dropped extremely down to 166.94 tons in 2005 using 432 trips. Even though the fishing effort was three times than that in 2005, anchovy production only went up almost twice in 2006. Simultaneously, the total effort gradually increased during the recovery process, but anchovy catch continued to show constant decline.

Table 3. Anchovy production, effort, and catch per unit effort from 1999-2012 in Krueng Raya

\begin{tabular}{|c|c|c|c|c|c|}
\hline Period & Year & Production (ton) $^{1}$ & Number of vessel ${ }^{2}$ & $\begin{array}{c}\text { Effort } \\
\text { (unit/trip/years) }^{2}\end{array}$ & CPUE \\
\hline \multirow[t]{6}{*}{ Before Tsunami } & 1999 & $1,905.58$ & 73 & 9,344 & 0.2039 \\
\hline & 2000 & $1,855.47$ & 72 & 9,216 & 0.2013 \\
\hline & 2001 & $1,833.11$ & 71 & 8,946 & 0.2049 \\
\hline & 2002 & $1,743.29$ & 68 & 8,568 & 0.2035 \\
\hline & 2003 & $1,053.47$ & 76 & 9,576 & 0.1100 \\
\hline & 2004 & $1,024.18$ & 73 & 9,198 & 0.1113 \\
\hline \multirow[t]{2}{*}{ After Tsunami } & 2005 & 166.94 & 6 & 432 & 0.3864 \\
\hline & 2006 & 272.12 & 18 & 3,067 & 0.1575 \\
\hline Recovery & 2007 & 182.32 & 24 & 2,715 & 0.059 \\
\hline \multirow[t]{5}{*}{ Process } & 2008 & 156.79 & 22 & 2,839 & 0.055 \\
\hline & 2009 & 129.82 & 23 & 3,086 & 0.048 \\
\hline & 2010 & 136.28 & 24 & 3,150 & 0.044 \\
\hline & 2011 & 129.87 & 26 & 3,325 & 0.039 \\
\hline & 2012 & 126.57 & 29 & 3,654 & 0.035 \\
\hline
\end{tabular}

Sources: 1APMAF (2000-2012) and 2Field Survey (2012)

A lift net boat operated from 18 to 22 days each month for a total of six months per year. PLL (2012) mentioned that these boats were not operated to maximum capacity, but only around $60-80 \%$ of the total capacity were used for fishing anchovies both before and after the tsunami. As a consequence, the number of vessels, total efforts, and anchovy catch fluctuated during the period 1999-2012 (Table 3).

Data revealed that CPUE in both the period 1999-2004 and 2007-2012 tend to decrease with increasing efforts (Figure 5). Correlation between CPUE as a dependent variable (y) and effort as an independent variable (x) was computed using SRA. According to SRA, we can propose two distinguishable models of anchovy MSY in Krueng Raya Bay. Model 1 represented the period before the tsunami with equation $\mathrm{y}=0.8696-$ 0.00008x and Model 2 addressed the period 2007-2012 with equation 
Factors Contributing to the Decline of the Anchovy Fisheries

$y=0.1138-0.00002 x$. Both models recommended the MSY of anchovy fisheries and the optimum effort to be spent in a managed area of Krueng Raya Bay (Table 4). To sustain the anchovy fisheries for each period, models 1 and 2 also performed the optimum number of 43 units and 23 units of lift net boats, respectively.

Before tsunami period

a. Correlation CPUE and Effort

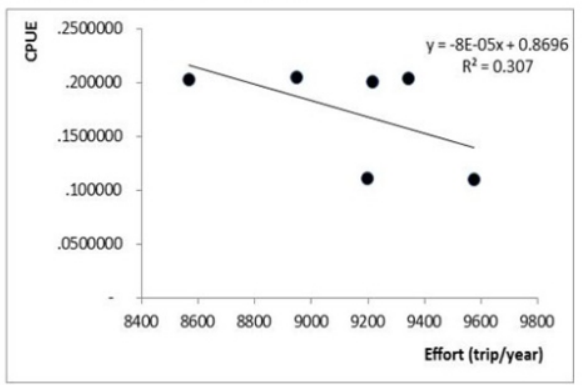

c. MSY Curve

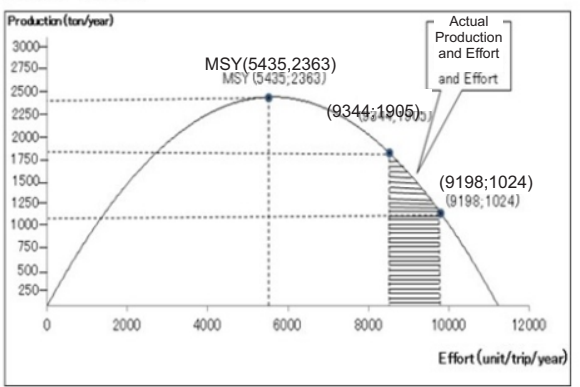

Recovery process period

b. Correlation CPUE and Effort

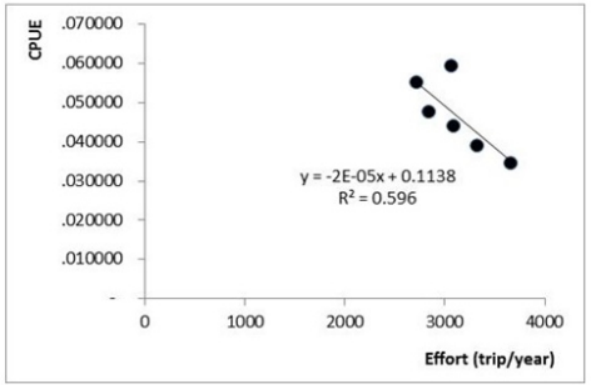

d. MSY Curve

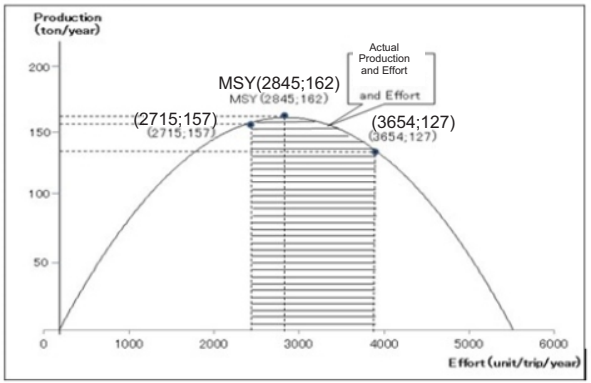

Figure 5. CPUE-effort correlation ( $a$ and $b$ ) and MSY curve (c and d) of achovy resources in the priod 1999-2012, Sorces: APMAF (2000-2012) and Data Analysis (2013)

Later on, anchovy's MSY curve can be directed using both constant (a) and coefficient (b) estimators (Figure 5). This research revealed that MSY in the period before tsunami (1999-2004) and recovery process (20082012) were 2,363.138 tons/year and 161.881 tons/year, respectively. Meanwhile, actual productions in the same period were in range of 1,024.18-1,905.58 ton and 126.57-156.79, respectively. According to Figures 4 actual production was less than anchovy's MSY, but the actual effort had already been over the optimum efforts as this model suggested for both periods. Interestingly the findings in this research were: (1) the fishery's MSY in the period of recovery process was 20 times less before the tsunami (Table 4); (2) the recent average catch in MSY was 53.9\% of 
MSY and it can be classified to the less abundant stock in before tsunami; and (3) the recent average catch in MSY went down to 5.5\% of MSY, it means the stock faced imminent depletion.

Table 4. Surplus production model and its calculation to estimate MSY and Optimum effort

\begin{tabular}{lccccc}
\hline Period & \multicolumn{2}{c}{ Estimator } & Model (Equation) & \multicolumn{2}{c}{ Result } \\
\hline & $\begin{array}{c}\text { Constant } \\
\text { (a) }\end{array}$ & $\begin{array}{c}\text { Coefficient } \\
\text { (b) }\end{array}$ & & $\begin{array}{c}\text { MSY (a } / 4 b) \\
\text { (ton/year) }\end{array}$ & $\begin{array}{c}\text { Optimum } \\
\text { Effort } \\
\text { (a/2b)(trip) }\end{array}$ \\
\hline Before Tsunami & 0.8696 & - tofts & $\mathrm{y}=0.8696-0.00008 \mathrm{x}$ & $2,363.138$ & 5,435 \\
\hline Recovery process & 0.1138 & - & $\mathrm{y}=0.1138-0.00002 \mathrm{x}$ & 161.881 & 2,845 \\
\hline
\end{tabular}

Source: Data Analysis(2013)

Anchovy identification and its characteristic role in fisheries management

As an initial research, we started to identify anchovy species and its characteristics in Krueng Raya Bay which was established as one of anchovy centers in Aceh Province prior to the 2004 tsunami. The distribution of anchovy in Aceh Province had been known in coastal waters of the Malacca Strait and the Indian Ocean from our observation during the period 2005-2012. However, there is no previous research carried out to define the characteristics of anchovy. In this case, the identification of anchovy as Stolephorus commersonii Lacepède (1803) in Krueng Raya Bay was an interesting task to initiate anchovy fisheries management in the future. The species has had widespread distribution in the Indian Ocean and Western Pacific (Whitehead et al., 1988), Ambon Bay (Sumadhiharga and Yulianto, 1987), Bima Bay-West Nusa Tenggara (Andamari et al., 2002), and Kabuy Bay-Raja Ampat (Bailey etal., 2007).

However, some characteristics of $S$. commersonii identification and its LWR analysis were inappropriate for the holistic determination of the stock concept in term of fisheries management purposes. Begg et al., (1999) concluded that a fundamental of fisheries management requirement is to consider the full impact of management actions, including identification of the stock complexity of a fish species. As morphometric study, LWR in this research was a small part of fish stock identification. Nowadays, anchovy that has had a negative allometric growth pattern was not only found in Krueng Raya Bay, but also this similar pattern of LWR was identified for anchovy in Bima Bay-Ambon Province (Andamari et al., 2002) and Cirebon's coastal water (Supriyadi, 2008). Samsun et al. (2004) also found that the anchovy functional regression was a negative allometric growth pattern $(b<3)$ in the Mid-black Sea. 
Paraskevi and Stergiou (2012) noted that the allometric growth model was (1) the most appropriate in describing fish morphometric relationship; and (2) study on effect of feeding habit and habitat to morphological characteristics. They stated that anchovy, as small pelagic filter feeder which prey on small zooplankton (copepods), has small mouth and strong dentition in adaption of food habit. Our research predicted that seasonal migration of $\mathrm{S}$. commersonii might have a relationship with food habit, monsoon season, enrichment of nutrient into water column regarding FGD with fishermen. Furthermore, oceanography and type of ecosystem; such as current, temperature, existence of mangrove and coral reef; might be contributed in establishment of anchovy population. For instance, the population strategies of European Anchovy to the seasonal upwelling ecosystem has relationship with the enrichment of coastal water and growth investment (Cubillos et al., 2001). Integration of anchovy identification, its characteristics and food habit, LWR, and factors contributing on seasonal migration should be paid attention on anchovy fisheries management in the future. Otherwise, these crucial factors might have influenced on un-sustainability of $S$. commersonii in Krueng Raya Bay.

Overfishing of anchovy fisheries prior to the tsunami disaster (1999-2004)

Overfishing of anchovy fisheries was shown by actual effort more than the optimum effort and actual production less than the MSY (see Figure 5c and Table 4). Indeed, anchovy stock could be considered into less abundant state, which is shown by the recent average catch in MSY (53.9\%). There were several major factors that caused overfishing of anchovy fisheries prior to the tsunami disaster. Firstly, the number of lift net boats definitely increased in the 1980s and the 1990s. In the earlier stage of anchovy fisheries development in the 1970s, only 2 lift net boats had been put into operation for fishing anchovy, according to PLL. The number of lift net boats rapidly increased to 70 units in the 1980 s, and reached 89 units in the 1990s. PLL mentioned that the number of fishing boats was 91 units just before the disaster in 2004.

Secondly, since the 1990s, equipment and materials used for fishing have become rapidly sophisticated with a sharp rise of productivity. In the earlier stage of development, the lift net boats used simple kerosene lamps in the 1970s and the 1980s; finally, they operated fluorescent lamps (capacity 10 watts) since the 1990 s to attract phytoplankton and small 
schooling fish, including anchovy. Motorization of pull boats equipped with outboard engine was a decisive factor to increase catch effort. In the last two decades, generators were equipped on board as power plant for light fishing to increase productivity. Each lift net boat was equipped with 25-40 white fluorescent lamps and one green lamp. Light intensity and distribution have influenced fish harvesting. For example, Sudirman et al. (1992) reported that using light intensity of 6,000 watts by lift net boats in the South Sulawesi waters since 1987 resulted to higher fish catch than those using 5,000 and 4,000 watts lamps.

Thirdly, the mesh size of the lift net fishing gear is becoming smaller. Fishermen used the mesh size $0.95 \mathrm{~cm}$ on the bottom side, $1.27 \mathrm{~cm}$ in the middle side, and $2.54 \mathrm{~cm}$ on the top side to construct a set of lift net fishing gear with wide $18 \mathrm{~m} \mathrm{X} 18 \mathrm{~m}$ and depth of around $15-20 \mathrm{~m}$. This fishing net is not selective, targeting juvenile stage of anchovy (fishermen knew such fish as small anchovy or "Teri Medan"), and catching all kind of small pelagic fish. In fact, the design of lift net also harvested the small size of anchovy (10-15 mm) during east and west monsoon seasons. As a consequence, stock of anchovy faced pressured condition and declined year after year, because it has no chance to reach sexual maturity stage. There is no special record the interval length of first stage maturity for $S$. commersonii. However, Luther (1979) reported that minimum size of $S$. commersonii at first maturity is $110 \mathrm{~mm}$ in the southwest coast of India. Andamari et al. (2002) mentioned that the maturity stage of $S$. commersonii was identified in average length $109.9 \pm 0.5 \mathrm{~mm}$ in Bima Bay.

Fourthly, anchovy is harvested throughout the year in both west and east monsoons. It might cause a decline of stock to support reproduction system of anchovy. In case of tropical anchovy, spawning season may have occurred throughout the year and reproductive seasons are often linked to the monsoon season (Tiews etal., 1970).

Other factors to boost anchovy fisheries depletion during the recovery process (2005-2012)

Overfishing of anchovy fisheries continued during the period 20052012. Because the actual production and fishing efforts were more than MSY and optimum efforts in the same period (Table 3 and Table 4), means anchovy fisheries was in overcapacity condition. FAO (2008) noted that overcapacity might occur when the fishing fleet is larger than it needs to be to catch the available fish resources. Lift net fisheries was in overcapacity 
Factors Contributing to the Decline of the Anchovy Fisheries

at around $16.7 \%$ by using the effort of 3,325 trips in 2011 . Thus, the number of lift net boats had to be reduced by 23 units for sustainable anchovy fisheries. Otherwise, anchovy resources sustainability would be threatened and depleted due to the recent average catch in MSY (5.5\% of MSY).

Besides the factors mentioned above, there are many other factors as to why anchovy fisheries showed depletion. Firstly, coral reef and mangrove ecosystem degradation might have contributed to anchovy depletion. There were no research activities conducted to analyze the state of this ecosystem in prior the tsunami in Krueng Raya Bay. According to the Center for Oceanography-Indonesia Research Institute (2005), coral reefs in the western part of Indonesia are in poor condition (35.7\%), including the reef in this study area. As an aftermath of the tsunami, the area, length and average living cover of the coral reef ecosystem were 196.4 ha, $13 \mathrm{~km}$ and 10\%, respectively (Long et al., 2006); and the live cover of hard coral was $36.9 \%$ (Ocean Diving Club, 2011). Therefore, the coral reef ecosystem was in poor condition based on the classification developed by McAllister (1988). It is estimated that $62-90 \%$ of this ecosystem was in degraded condition. We also observed that the point of Akhmad Rahmanyang peninsula and Lhok Mee Beach are frequently used for harvesting the small anchovy during October-November in the west monsoon.

Commonly, coral reef damage in the study area has been caused by increasing intensity of line boat activities, anthropogenic factors, and tsunami impact. Increasing number of line boats to $31.3 \%$ before the tsunami might have contributed to the destruction of coral reef ecosystems because these boats captured reef fish as a target species. These boats also frequently dropped anchors on reefs that can cause severe damage to coral reef ecosystems.

Anthropogenic factors have simultaneously occurred toward contributing to anchovy depletion after the tsunami. Nowadays, potassium cyanide that can kill coral polyps, symbiotic algae, and other small organisms necessary for healthy reefs has been used to catch ornamental reef fish by some fishermen in the study area. Explosives, landbased pollution, destructive fishing, oil spills, sand mining and untreated human sewage might have exerted much stress towards coral reef degradation. Indeed, mangrove conversion, deforestation, agriculture, shipping and harbor construction have destroyed the coral reef ecosystem indirectly. 
The tsunami also affected the mangrove ecosystems in Krueng Raya Bay. It is estimated that 77.1 ha of mangrove ecosystem is distributed along a $15.27 \mathrm{~km}$ stretch within the Aron Meudawa-Ujung Teungku Peninsula zone. The percentage cover of mangrove trees had remained at around $5 \%$ and it can be classified as under the severely damaged category according to the Ministry of Environment Classification (2004). In the 1980s, the mangrove area was estimated at around 300 ha in Krueng Raya Bay. The mangrove ecosystem has been converted into brackish water shrimp ponds which might be a major factor for the ecosystem degradation in this area. As a comparison, Wibisono and Suryadiputra (2005) reported that 26,823 ha mangrove ecosystem in Aceh Besar District was affected by the huge tsunami disaster. However, the tsunami's effect was less than the other anthropogenic impacts on the mangroves which are harvested for charcoal, housing and fire wood.

Secondly, rapid human population growth in Krueng Raya Bay after the tsunami disaster has urged fishing communities to depend more on fisheries resources (in particular anchovy) than before the 2004 tsunami. Before the disaster, around $69 \%$ of the population in this region had been dependent on capture fisheries and $31 \%$ on other livelihoods such as agriculture and livestock. After the tsunami disaster, those who were engaged in capture fishery and relied on it for their income increased to $78 \%$. Lotze et al. (2006) stated that rapid human population growth caused an increasing demand, commercialization of resources, technology development, unselective and destructive fishing gears that caused a sharply upward trend on fish resources depletion. They added that human activities have impacted to more than $90 \%$ of important species depletion; and $60 \%$ sea grass and wetlands habitat destroyed, water quality degradation, and accelerated species invasion.

\section{CONCLUSION}

Anchovy, identified as Stolephorus commersonii, has a significant role to sustain livelihood for the fishing communities in Krueng Raya Bay. Increasing utilization and dependency of anchovy resources caused the decline of anchovy fisheries which is increasingly unable to support fisheries livelihood after the 2004 tsunami. As a consequence, anchovy fisheries was over exploited during the period 1999-2004 and became deplete in the period 2005-2012.

There are several factors that contributed to overfishing anchovy 
Factors Contributing to the Decline of the Anchovy Fisheries

fisheries prior to the tsunami. The lack of anchovy characteristic knowledge, increasing effort, non-selective mesh size, unlimited use of lighting, harvesting throughout the monsoon season were direct factors contributing to anchovy overfishing. Anthropogenic factors definitely caused the degradation of coral reef and mangrove ecosystem and these factors could be indirect factors on the decline of anchovy fisheries prior to the tsunami.

Anchovy fisheries faced overfishing and depletion condition due to the actual production of anchovy and average recent catch in MSY. This anchovy fisheries depletion can lead to at least six scenarios, as follow: (1) anchovy resources suffered under extreme pressure during the critical years (2005-2006), (2) the direct factor continued contributing on anchovy resource declining during recovery process, (3) the destructive fishing operations threaten the coral reef ecosystem, (4) the anthropogenic factors lead to coral and mangrove ecosystem degradation, (5) tsunami impact compounds the degradation of coastal ecosystem; and (6) the population increase caused the increase of anthropogenic factors and dependency on anchovy resources. However, it is clear that the tsunami impact on anchovy resources depletion may be lesser than the combined effects of destructive fishing and anthropogenic factors.

On a positive note, anchovy depletion can be turned around to avert another anchovy fisheries collapse in the future. To prevent such a bigger "tragedy of the commons," the Government of Aceh Province (GOAP) needs to prepare "Good Governance of Anchovy Fisheries Management, GGAFM" in the future. Within a short time (1-5 years), the GOAP should conduct research on the unit stock to generate new baseline data of anchovy resources, information dissemination for preventing destructive and ecologically un-friendly fishing gear utilization for anchovy catch, and the greater involvement of society in the management of coastal ecosystems for anchovy resources. The Zoning and Management Plan must be prepared to integrate multi-purpose uses of the coastal zone of Krueng Raya Bay for the next 5-10 years. The most interesting scenario is to keep anchovy fisheries sustainable by integrating the indigenous institution (Panglima Laot Lhok) and district governments in managing fisheries resources by using social ecological approach and establishing Marine Protected Areas in the long run (25 years). This recommendation will be useful to further conserve anchovy resources and the ecosystem, thus potentially contributing to an increase in income of fishing communities in Krueng Raya Bay. 


\section{ACKNOWLEDGMENT}

The first author would like to express his thanks and appreciation to the Directorate General of Higher Education and Center for Coastal and Marine Resources Studies who always provided support and encouragement in the conduct of this study. We appreciate the valuable help of all fishermen and Panglima Laot Lhok Krueng Raya who participated in the interview research, Dr. Lawrence M. Liao, visiting professor of the Graduate School of Biosphere Science, Hiroshima University for his academic suggestions, and Mr. Rachmad Firdaus for geographic information system assistance.

\section{REFERENCES}

ACEH PROVINCE OF MARINE AFFAIR AND FISHERIES. 2000-2012. .

ANDAMARI, R., D. MILTON and T. ZUBAIDI. 2002. Reproductive biology of five species of anchovy (Engraulidae) from Bima Bay, Sumbawa, Nusa Tenggara. Indonesia Journal of Agriculture Science 3 (2): 37-42.

BAILEY, M., C. ROTINSULUB, and U.R. SUMAILAA. 2008. The migrant anchovy fishery in Kabui Bay, Raja Ampat, Indonesia: Catch, profitability, and income distribution. Marine Policy 32: 483-488.

BEGG, G.A., K.D. FRIEDLAND, and J.B. PEARCE. 1999. Stock identification and its role in stock assessment and fisheries management: an overview. Fisheries Research 43: 1-8.

BRR NAD-NIAS. 2006. MapFrame for Aceh and Nias.

CENTER FOR OCEANOGRAPHY-INDONESIA RESEARCH INSTITUTE. 2005. The state of coral reef ecosystem in 2003. Report.

CLARK, W.G. 1977. The lessons learns of the Peruvian anchoveta fishery. California Cooperative Oceanic Investigation Report 19: 57-63.

CUBILLOS, S.A., D.F. ARCOS., D.A. BUCAREY, and M.T. CANALES. 2001. Seasonal growth of small pelagic fish off Talcahuano, Chile $\left(37^{\circ} \mathrm{S}\right.$, $73^{\circ} \mathrm{W}$ ): a consequence of their reproductive strategy to seasonal upwelling? Aquat. Living Resour. 14:115-124. 
Factors Contributing to the Decline of the Anchovy Fisheries

DASKALOV, G.M., AND E.V. MAMEDOV. 2007. Integrated fisheries assessment and possible causes for the collapse of anchovy kilka in the Caspian Sea. ICES J. Mar. Sci. 64 (3): 503-511.

FAO. 2008. Fisheries Management, Managing Fishing Capacity. FAO Technical Guidelines for Responsible Fisheries. No. 4, Suppl. 3: 104.

GAYANILO, F.C. Jr., D. PAULY. 1997. FAO-ICLARM Stock assessment tools (FISAT) reference manual. FAO Computerized Information Series (Fisheries) No. 8. Rome: 262 p.

GAERTNER, D., A. FONTENEAU, and F. LALOË. 2001. Approximate estimate of the maximum sustainable yield from catch data without detailed effort information: application to tuna fisheries. Aquat. Living Resources 14: 1-9.

HILBORN, R., AND C.J. WALTER. 2001. Quantitative fisheries stock assessment: choice, dynamics and uncertainty. Kluwer Academic Publisher, USA, pp. 18-21.

IMRAN, Z., M. YAMAO. 2014. Factors affecting changes of fisheries livelihood 7 years after the Asian Tsunami in Krueng Raya Bay, AcehIndonesia. Journal of Regional Fisheries 54 (2): 1-24.

INDIAN OCEAN TUNA TAGGING PROGRAM. 2000. Working Document of Meeting Report.

LISNA AND SOFYAN. 2011. Efficiency analysis of marketing in fisheries agro-industry: A case study marketing of dried anchovy in Meunasah Keudee Village, Aceh Besar District. Agrisep 12 (1): 1-8.

LONG, B.G., A. HAMDANI, G. DANREWS, J. COURBOULES, Z. IBROS, M. SDIAGA, P.J.B. SCOTT, A. SIREGAR, and K. MANSYUR. 2006. Aceh nearshore atlas dan draft marine zonation plan. Marine and Coastal Resources Management Project [Asian Development Bank Loan No. 1770-DIO (SF)] Department of Fisheries. Jurnal Perikanan dan Kelautan Tropis 7 (1): 6-11. 
LOTZE, H.K., H.S LENIHAN, B.J. BOURQUE, R.H. BRADBURY, R.G. COOKE, M.C. KAY, S.M. KIDWELL, M.X. KIRBY, C.H. PETERSON, and J.B.C. JACKSON. 2006. Depletion, degradation, and recovery potential of estuaries and coastal seas. Science 312: 1806-1809.

LUTHER, G. 1979. Anchovy fishery of southwest coast India with notes on the characteristics of the resources. India Journal of Fisheries 26: 2329.

MCALLISTER, D.E. 1988. Environmental, Economic, and Social costs of coral reef destruction in the Philippines. Galaxea 7: 161-178.

MIFTACHHUDDIN. 2003. Opportunities and economics diversity of fishermen wife household in Aceh Besar District: A simulation analysis. Master Thesis, Graduate School of Bogor Agricultural University, Bogor, Indonesia.

MINISTRY OF MARINE AFFAIR AND FISHERIES. 2011. Marine and fisheries in figure 2011. Book, Jakarta, Indonesia, p. 7.

MINISTRY OF MARINE AFFAIR AND FISHERIES. 2012. Capture fisheries statistics of Indonesia 2011. Book, Jakarta, Indonesia, p. 5.

MOHAMMED, K.S., T.V. SATHIANANDAN, P.U. ZACHARIA, P.K. ASOKAN, P.K. KRISHNAKUMAR, K.P. ABDURAHIMAN, V.S. SHETTIGAR, and D.N. RAVEENDRA DN. 2010. Depleted and collapsed marine fish stocks along south-west coast of India-a simple criterion to assess the status. In: Coastal fishery resources of India; conservation and sustainable utilization (B. Meenakumari, M.R. Boopendranath, L. Edwin, T.V. Sankar, N, Gopal, and G. Ninan, eds). Society of Fisheries Technologists, Cochin, pp. 67-76.

MUCHLISIN, Z.A., N. FADLI, A.M. NASUTION, R. ASTUTI, M. MARZUKI, and D. MUSNI. 2012. Analisis subsidi perikanan non BBM di Kabupaten Aceh Besar, Provinsi Aceh. Fisheries subsidy analysis on non-fuel in Aceh Besar District, Aceh Province. Depik 3 (1): 175-182.

OCEAN DIVING CLUB. 2011. Reef check in Krueng Raya Coastal Waters. Report. 
Factors Contributing to the Decline of the Anchovy Fisheries

ONGKERS, O.T.S. 2012. Relationship between capacity of growth biomass and exploitation level shorthead anchovy (Encrasicholima heteroloba) in inner Ambon Bay. PhD Thesis, Graduate School of Bogor Agricultural University, Bogor, Indonesia.

PARASKEVY, K., K.I. STERGIOU. Morphometrics and algometry in fishes. In: Morphometric (C. Whal, eds). Intech, Croatia and China, pp. 65-86.

PAMEROY, R.S. 2012. Managing overcapacity in small-scale fisheries in Southeast Asia. Marine Policy 36: 520-527.

REGIONAL DEVELOPMENT PLANNING AGENCY OF ACEH PROVINCE. 2006. Zonning Plan of Aceh Province.

SAMSUN, O., N. SAMSUN, A.C. KARAMOLLAĞLU. 2004. Age, growth, mortality rate of the European Anchovy (Engraulis encrasilcolus L, 1758) off the Turkish Black Sea. TurkJ VetAnim Sci 28: 901-910.

SUDIRMAN, MUSBIR, and M.N. NESSA. 1992. Light Fishing in Wallacea Area, Sustainable or Destructive?. Working Paper, pp. 1-10.

SUMADHIHARGA, K., AND YULIANTO. 1987. Pengamatan beberapa aspek biologi dan masalah yang dihadapi perikanan ikan umpan di Teluk Ambon. Observation on biology aspect and problem of bait fishery in Ambon Bay. Biologi Perikanan dan Geologi: 29-35.

SUPRIADI. 2008. Dampak perikanan panyang terhadap kelestarian stok ikan teri nasi (Stolephorus spp) di Perairan Cirebon dan altenatif pengelolaannya. Boat seine impact on sustainability of anchovy in Cireborn's Coastal Water and its alternative management. Undergraduate Thesis, Bogor Agricultural University, Bogor, Indonesia.

TIEWS, K., I.A. RONQUILLO, and L.M. SANTOS. 1970. On biology of anchovies (Stolephorus lepecede) in Philipinnes water. Proceeding of the Indo-Pacific Fisheries Council 13 (2): 20-48. 
WHITEHEAD, P.J.P., G.J. NELSON, T. WONGRATANA. 1988. FAO species catalogue. Clupeid fishes of the world (Suborder Clupeoidei). An annotated and illustrated catalogue of the herrings, sardines, pilchards, sprats, shads, anchovies and wolf-herrings. Part 2 Engraulididae. FAO Fisheries Synopsis 7: 305-579.

WIBISONO, I.T.C., AND I.N. SURYADIPUTRA. 2005. Study of lessons learned from mangrove/coastal ecosystem restoration efforts in Aceh since the tsunami. Wetlands International - Indonesia Programme, Bogor, p. 86. 